\title{
Therapeutic Effects of Modified Gengnianchun Formula on Stress-Induced Diminished Ovarian Reserve Based on Experimental Approaches and Network Pharmacology [Erratum]
}

\section{Gao L, Zhang Y, Xu H, Zhao F, Wang W. Drug Des Devel Ther. 2020;14:4975-4992}

The authors have advised that there was an error in the author list on page 4975 which was introduced by the Editorial staff during the publication process.

The correct author list and affiliations are as follows:

$$
\begin{aligned}
& \text { Lingyun Gao',2,* } \\
& \text { Yang Zhang }{ }^{1,2, *} \\
& \text { Huangfang Xu }{ }^{2} \\
& \text { Fangui Zhao,3 } \\
& \text { Wenjun Wang }
\end{aligned}
$$

'Department of Integrated Traditional Chinese Medicine and Western Medicine, Obstetrics and Gynecology Hospital of Fudan University, Shanghai, 2000I I, People's Republic of China; ${ }^{2}$ Shanghai Key Laboratory of Female Reproductive Endocrine Related Diseases, Shanghai 2000II, People's Republic of China; ${ }^{3}$ Department of Ultrasound Diagnosis, Obstetrics and Gynecology Hospital of Fudan University, Shanghai, 2000 I I, People's Republic of China

\section{*These authors contributed equally to this work}

There was also an error on page 4990. Acknowledgment section, the acknowledgment "Lingyun Gao and Yang Zhang are joint first authors" was not included by Editorial staff.

\section{Publish your work in this journal}

Drug Design, Development and Therapy is an international, peerreviewed open-access journal that spans the spectrum of drug design and development through to clinical applications. Clinical outcomes, patient safety, and programs for the development and effective, safe, and sustained use of medicines are a feature of the journal, which has also

been accepted for indexing on PubMed Central. The manuscript management system is completely online and includes a very quick and fair peer-review system, which is all easy to use. Visit http://www. dovepress.com/testimonials.php to read real quotes from published authors. 